\title{
Implementation Image Based Tracking Augmented Reality on The Promotion Brochure of Honda Matic Motorcycles
}

\author{
Riko Raynol Hasan \\ Software Engineering Technology, \\ Agricultural Polytechnic of \\ Samarinda, Samarinda, 75131, \\ Indonesia \\ rikoraynol12345@gmail.com
}

\author{
Reza Andrea* \\ Software Engineering Technology, \\ Agricultural Polytechnic of \\ Samarinda, Samarinda, 75131, \\ Indonesia \\ reza@bibirdesign.com \\ *Corresponding author
}

\author{
Syafei Karim \\ Software Engineering Technology, \\ Agricultural Polytechnic of \\ Samarinda, Samarinda, 75131, \\ Indonesia \\ syfei_karim@politanisamarinda.ac.id
}

\begin{abstract}
In this research is motivated by the absence of other alternatives in terms of supporting the promotion of Honda automatic motorcycles because until now the Honda dealer PT. Tunas Dwipa Matra only uses brochures as a promotional medium and this still has a shortage of potential customers who can only see the motorcycles with 2D images and cannot see every angle on the motorcycles. So in this case the customer certainly needs an application so that they can help see the visual appearance in $3 \mathrm{D}$ and also help them see the product in an informative manner that is directly contained in the application, with that there is a technology that can be used called Augmented Reality (AR). AR is a combination of $3 \mathrm{D}$ or $2 \mathrm{D}$ virtual objects and virtual objects that will blend into the real world. This study uses the image-based tracking method which is part of markerbased tracking where the marker is a brochure using a brochure that is readily available from the company. From this research, an Augmented Reality application for a Honda Matic motorcycles named Ar Motic will be built using the Unity application with the Vuforia Software Development Kit (SDK) for tracking brochures to display 3D objects and the Blender application that helps in making 3D models (Selvia, 2019).
\end{abstract}

Keywords-Augmented Reality, Promotion Media, Honda Matic Motorcycle, Image Based Tracking

\section{INTRODUCTION}

Promotion in the technology information sector was growing rapidly on the otomotif sector specifically in motorcycle. Many people used the motorcycle, it make the motorcycles company using the promotions with brochure media. But the brochure media has a weakness. If the customer takes the brochure to home, they just see the motorcycle in the brochure on the two dimensions (2D). It makes the customer need a application to helps see the motorcycle on the three dimensions (3D). The application created using augmented reality.

Based on the research which is the implemented by Hermawan and Hariadi (2015) in the visual augmented reality (AR) image is a combination of $3 \mathrm{D}$ or $2 \mathrm{D}$ virtual objects and virtual objects that will blend into the real world. Augmented reality is a variation of the Virtual Environment (VE), which is a combination of VR technology or better known as Virtual Reality (VR). The virtual reality means a situation where the overall user is in a virtual environment.

AR technology is currently often used on smartphones, which is one of the most widely used platforms and the Android operating system is embedded. Technology will increasingly develop specifically on the augmented reality sector. It depending on the development of smartphone technology. Augmented reality used in many sector. Some sector used augmented reality is medical sector, military and otomotif sector.

The applications testing will applied in the PT. Tunas Dwipa Matra, it is a company of Honda motorcycle authorized dealer. They sell various Honda motorcycles including the Scooter Matic. The application will help the customer to see motorcycles in the brochure on 3D using augmented reality. The application will help to see the specification of motorcycle using the smartphone camera. The strengths of application will be help the customer to get the information about the motorcycle they want.

In this research, using image based tracking method. It is a one of marker based tracking. Brochure will be the marker. Using the brochures that have been available from the company. There is no need to marker again. In the implementation needed the vuforia sdk, it is tools to make an augmented reality.

\section{LITERATURE REVIEW}

Several studies are used as guidelines and references in making this application, among others. According to research from Hermawan and Hariadi (2015) in their research entitled Utilization of Augmented Reality as Campus Information Media Using Brochures which discusses the use of brochures as a more interactive campus information medium using Augmented Reality technology. Information that has not been included in the brochure can be displayed virtually without additional 
brochures. So that savings in raw materials and costs can also be made (Reynaldi, 2018).

In Setyawan's (2016) study entitled Analysis of the Use of the Marker Tracking Method in the Augmented Reality of Traditional Central Java Musical Instruments which discusses a comparative analysis between the two marker tracking methods, namely marker based tracking and markerless which aims to have a success rate in bringing up good objects. So that research will be carried out to find the level of effectiveness of a better marker tracking method and things that can affect the success rate of the augmented reality application in bringing up objects by looking at the parameters that influence it, namely the distance of the marker and the color used to be used as a marker in augmented reality.

The research entitled Assembly Augmented Reality Against An Android-Based Car Ad Design researched by Hunaepi (2016) aims as a tool for business people to market products in modern varied visualizations, the benefits of research in this research are useful for knowledge about augmented reality, as well as providing benefits for informatics students in particular and society in general and can be useful for the automotive trading industry, especially car vehicles.

According to research from Febri Hadi, et al (2018) in his research entitled Application of augmented reality in the new yamah a tjahaja brochure for android-based promotion which discusses the use of brochures as a motorcycle promotion medium using Augmented Reality technology. This study changes the system from 2D which is only seen in one angle to 3D which can display vehicle details using the help of an android smartphone.

Research entitled Development of Mobile Product Promotion Applications Using Augmented Reality Technology on Android Mobile which was researched by Lorena and Purnamasari (2019) in order to make something in the virtual or virtual world look real, so that it can add value to a product for the company and add value to information for consumers and also in the application there is a purchase feature to an online store to make it easier for consumers to get the product directly.

\section{A. Brocure}

According to Hermawan and Hariadi (2015) brochure is an information medium that functions to provide an explanation of a product, public facilities, company profile, school, or brochure as a means of advertising.

\section{B. Automatic Motorcycle}

Matic is an abbreviation of the term automiatic which refers to the motorbike's gear operating system which is automatically regulated by the vehicle engine itself Wicaksono et al. (2016).

\section{Augmented Reality}

Augmented Reality is a technique for combining the real world into the virtual world. This technique allows an object in the virtual world to be displayed with other objects simultaneouqsly Ricman Roedavan (2015), There are three principles of Augmented Reality. The first is that AR is an amalgamation of the real and virtual worlds, the second run interactively in real-time, and the third is integration between objects in three dimensions, namely virtual objects integrated with the real world according to Ronald T. Azuma (1997) in Hunaepi (2016).

1. Vuforia Software Development Kit

In Lorena and Purnamasari (2019) Vuforia is a Software Development Kit (SDK) that allows the development of Augmented Reality applications on mobile devices with support for Android, iOS and Unity3D extensions to be built. Vuforia has a robust architecture for optimizing the tracking, registering, and graphics visualization processes enabling a variety of features for tracking and registering frame markers, images, and text.

2. How Augmented Reality works

According to Lorena and Purnamasari (2019) Augmented Reality works based on image detection (images), and the image used is a marker. The working principle is that a calibrated camera will detect the marker given, then after recognizing and marking the marker pattern, the webcam will make a comparison whether the marker matches the existing database. If not, then marker information will not be processed, but if appropriate, marker information will be used to render and display 3D objects or animations that have been previously made. In Picture 1, you can see how the AR marker works where the user has to point the smartphone camera at the marker.

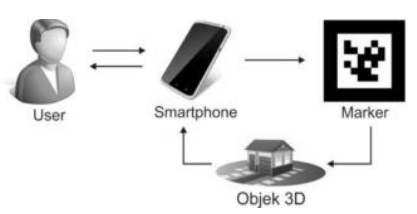

Picture 1. How Augmented Reality Works

\section{Multimedia}

According to Vaughan (2004) in Hermawan and Hariadi (2015) multimedia is a combination of text, art, sound, images, animation, and video delivered by computer or manipulated digitally and can be delivered and/or controlled interactively. There are 3 types of multimedia are:

1. Interactive Multimedia

2. Hyperactive multimedia

3. Linear multimedia

4.

E. Unity $3 D$

Unity is a game engine that allows you, both individuals and teams, to create a 3D game easily and quickly Ricman Roedavan (2015).

\section{F. Blender}

According to Ardhianto, et al. (2012) Blender is an open source software that is used to create multimedia content, especially 3D dimensions, there are several advantages that Blender has over similar software. Here are some of the advantages: 
1. Open Source

2. Multi Platform

3. Update

4. Free

5. Complete

6. Mild

7. Open Community

\section{G. Image Based Tracking}

Image-Based Tracking is part of Marker Based Tracking, which is an AR method for reporting markers and identifying patterns from markers which will later reveal a visual object into the real environment Chari (2008) in the journal Satria and Prihandoko (2018).

\section{RESEARCH METHODS}

Testing the results of this application will be carried out at PT. Tunas Dwipa Matra in the Keledang River area, Samarinda. Includes activities including research preparation, material gathering, and thesis writing.

The research stages that will be carried out in this research are using the multimedia development stage, with an approach starting from concept, design to distribution. In Picture 2 the stages of this research stage:

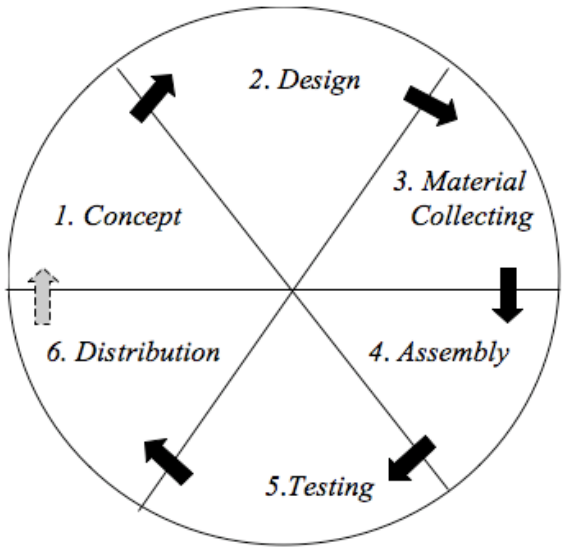

Picture 2. Multimedia development stages

1. Concept

Formulate the basics of a multimedia project that will be created and developed by designing the basic designs on which the application will be built.

In Image 3 below, this application use the Use Case Diagram is the flow of the Honda Matic Augmented Reality application process starting from the user when selecting the camera to the application system. In the application system, there are several use cases displaying objects, features and others in the augmented reality application.

2. Design

Make a mockup of the application interface, create an image of the object to be displayed and the flow of the application.

3. Material Collecting

Is the stage of collecting object data and materials that will be useful in making applications.
4. Assembly

The stages of making an application include the user interface design stage, code generation, $3 \mathrm{~d}$ object creation and the process of compiling a target image that is adjusted to the $3 \mathrm{~d}$ object on the brochure.

5. Testing

The testing phase is carried out after completing the assembly stage by running an application or program and seeing whether there is an error or not. The first stage at this stage is called the alpha testing stage or functional testing where the test is carried out by the manufacturer or the manufacturer's own environment. After passing alpha testing, beta testing involving end use will be carried out. When testing beta, the method used is the User Acceptance Testing (UAT) method. UAT is a testing process carried out by users with the output of a test result document that can be used as evidence that the software has been received and has met the requirements requested (Sprinting, 2017).

6. Distribution

At this stage, the application will be stored in a storage medium. If there is not enough storage media to accommodate the application, compression of the application will be performed.

This stage can also be called the evaluation stage for developing finished products to make them better. The results of this evaluation can be used as input for the concept stage of the next product.

\section{RESULT AND DISCUSSION}

The following is a display of the results of the making of the Honda motorbike augmented reality application.

A. Result

1. Assembly Interface

Assembly interface is a display of the application being built (Riyans, 2018). The following are some of the interfaces contained in the application:

- On the main page in Picture 3 there are several buttons including Augmented Reality, Help, Info, and Exit.

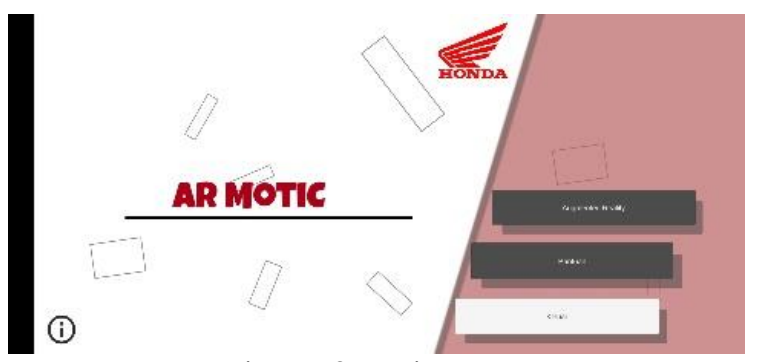

Picture 3. Main Menu

- In Picture 4 AR will display the camera where the camera is pointed at the marker/brochure so that the 3D motor object appears according to the brochure image. 


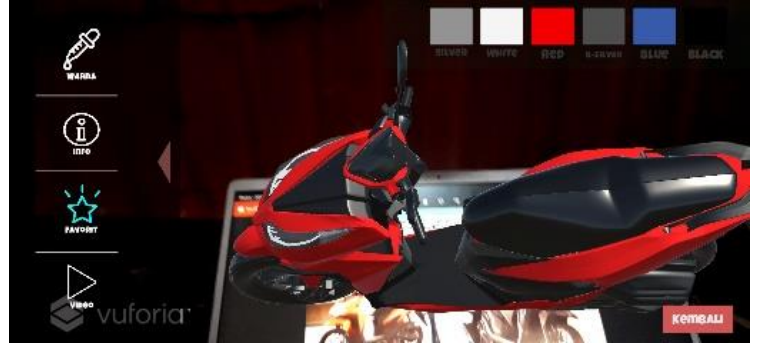

Picture 4. AR Camera

If the user clicks the arrow button on the left side of the screen it will enter the features menu, where the features consist of colors, info, favorites and videos.

- It can be seen in Picture 5 that the favorite view contains all the objects that we save that are on the AR menu, on this menu the user can select the object that was previously saved and then the object will be displayed without using a marker or brochure.

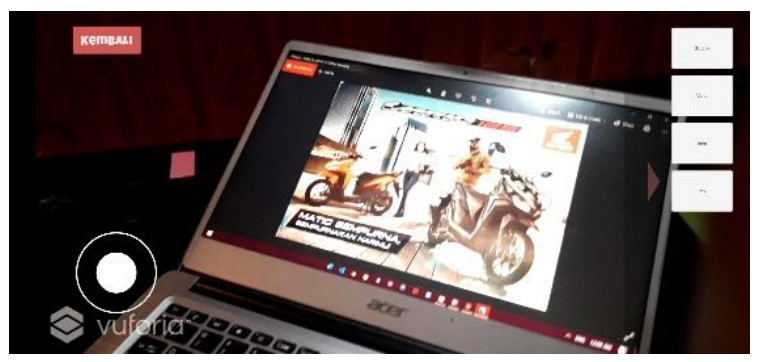

Picture 5. Favorit Camera

On the right side of the screen appears the object button that we save, if the user clicks on the button the $3 \mathrm{D}$ object that we save will appear, then the user can move as desired, can be seen in Picture 6 .



Picture 6. Object In Camera Favorit

2. Application Assembly

Application assembly is the creation of an application that is built, here are some of the manufacturing contained in the application.

- Making 3D object models is made using Blender software, there are 6 3D objects made including Beat eSP, Vario eSP, Genio 2019, Scoppy Stylish, PCX 2019, and ADV 2019 which are made based on the motor model of each object can be seen in Picture 7.

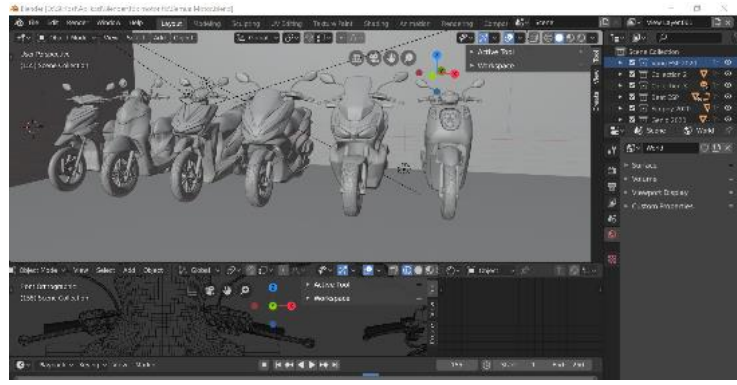

Picture 7. 3D Model

- Making AR applications is made using Unity software and also using the Vuforia SDK to implement Augmented Reality (Siltanen, 2012).

> Assembly Marker

In Picture 8 The markers that used are brochures which consist of brochures Beat esp, Vario esp, Genio, Pcx, Scoppy Stylish 2019, Adv which will be adjusted to each 3D where 3D will appear when the brochure is directed to the camera.

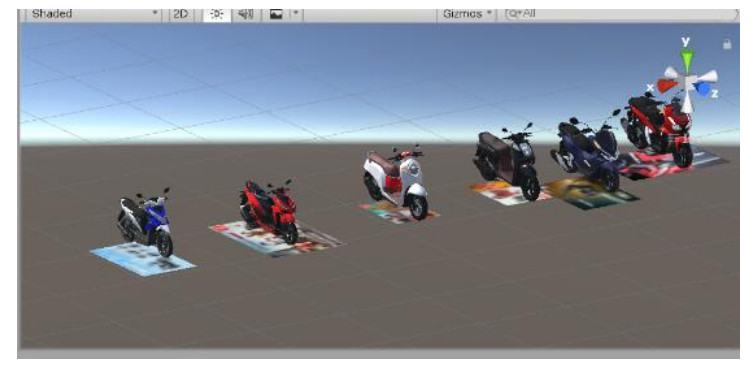

Picture 8. Marker and Brocure.

Upload markers to Vuforia database

Before uploading a marker to the Vuforia database, the first thing to do is to get a License Key. And then the existing markers or brochures will be uploaded to the Vuforia database

$>$ Download the package from the database

The result of the download is in the form of a Unity package which will then be imported into the Unity application where the package is directly entered into the project in Unity.

$>$ Making of Augmented Reality To create augmented reality, the Unity application is required. Applications that will display AR cameras and also the features available in the application.

- Applications that have been completed in Unity will be built on the android platform.

- The application that has been built will be carried out in the installation stage on an android smartphone where after installing this application, the tracking process on the brochure where the brochure is a marker that will start from the image input stage, where the processor processes real time frame by frame from the captured image. The next stage, which is the image threshold process, can be seen in Picture 9, where each frame carries 
out this process until the image produces black and white. In the process of producing black and white, the objective is to find out each shape and pattern of each captured image frame. The tracking process is to detect markers that consist of 4 stages, namely contour extraction, corner detection, pattern normalization, and template matching.

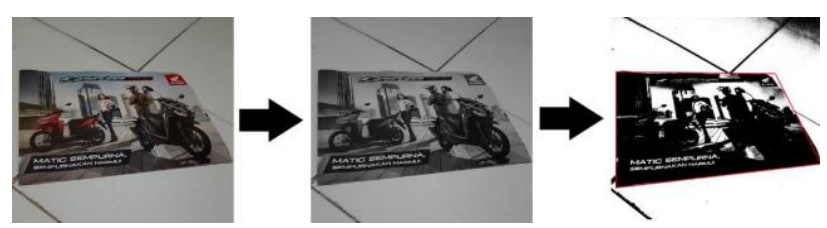

Picture 9. Image Threshold Stage

The contour extraction and corner detection process use a black and white image obtained at the stage image threshold to obtain the coordinates. Picture 10 shows the next stage, namely pattern normalization, which aims to make the marker take a normal shape, and then the template matching process can be done correctly.

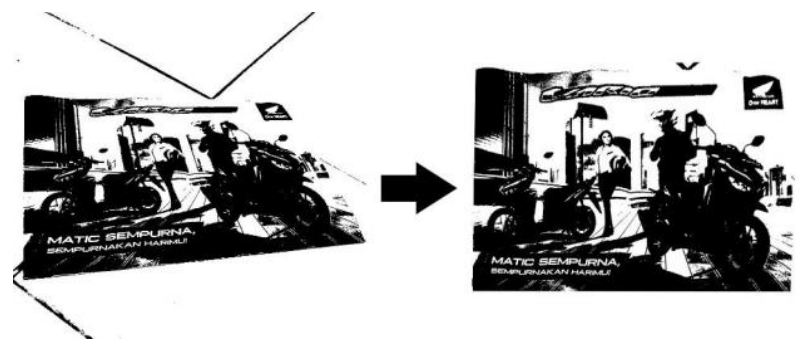

Picture 10. Pattern Normalization and Template Matching

The last stage is the relationship between the 3 coordinates, namely the $\mathrm{x}, \mathrm{y}$, and $\mathrm{z}$ coordinates, which can be seen in Picture 11, which plays an important role in which the $3 \mathrm{~d}$ object will be placed in the position of the object that has been adjusted beforehand.

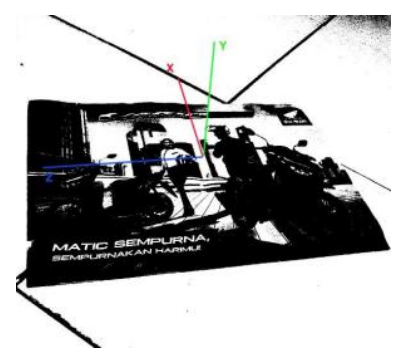

Picture 11. Coordinate $\mathrm{x}, \mathrm{y}$, dan $\mathrm{z}$

After that, the $3 \mathrm{~d}$ object will appear if the user points the camera at the marker, Picture 12, the results on the application camera when the user points to the brochure.

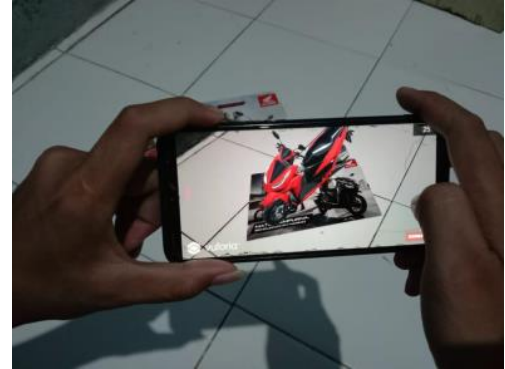

Picture 12. Applications Directed To Brochures

\section{B. Testing}

After the assembly is carried out in the application, the next step is to carry out the application testing stage, which aims to make the system being assembled according to what is needed. In functional testing phase, the application testing is carried out directly and will be monitored by the developer using several devices, where the developer will test the functionality of the features available from the application. There is a test scenario which can be seen in Table 1 .

Table 1. Test Result Scenarios

\begin{tabular}{|l|l|}
\hline \multicolumn{1}{|c|}{ Testing } & \multicolumn{1}{|c|}{ Expected results } \\
\hline Instal Apk & $\begin{array}{l}\text { The installation process is installed } \\
\text { properly on an Android Smartphone }\end{array}$ \\
\hline $\begin{array}{l}\text { Run the installed } \\
\text { application }\end{array}$ & $\begin{array}{l}\text { Applications running and open } \\
\text { properly }\end{array}$ \\
\hline $\begin{array}{l}\text { Starting AR Camera } \\
\text { and Favorites }\end{array}$ & The camera works fine \\
\hline $\begin{array}{l}\text { Detection of markers } \\
\text { that are incompatible } \\
\text { with the system }\end{array}$ & Cannot display 3D motor objects \\
\hline $\begin{array}{l}\text { Detection of the same } \\
\text { and adjusted markers } \\
\text { (Marker Based }\end{array}$ & Can bring up 3D motor objects \\
Tracking) & $\begin{array}{l}\text { Changing the color of the 3D motor } \\
\text { Color button is pressed } \\
\text { object }\end{array}$ \\
\hline $\begin{array}{l}\text { The info button is } \\
\text { pressed }\end{array}$ & $\begin{array}{l}\text { Issues information about } \\
\text { specifications and features according } \\
\text { to the 3D motor object }\end{array}$ \\
\hline $\begin{array}{l}\text { The favorite button is } \\
\text { pressed } \\
\text { menu favorite camera }\end{array}$ & $\begin{array}{l}\text { Favorite button will change to blue } \\
\text { color where 3D object is stored and } \\
\text { button on favorite camera will } \\
\text { appear }\end{array}$ \\
\hline $\begin{array}{l}\text { Fideo player playback } \\
\text { button is pressed }\end{array}$ & A video billboard will appear. \\
\hline Smooth video player playback. \\
\hline cameras.
\end{tabular}

To conduct testing, the developer uses several android smartphone devices, amounting to 5, where each smartphone has different specifications, which can be explained in table 2 . 
Table 2. Android Specification

\begin{tabular}{|c|c|c|c|}
\hline Spec & Device 1 & Device 2 & Device 3 \\
\hline $\begin{array}{l}\text { Smartphone } \\
\text { Name }\end{array}$ & Vivo Y83 & Redmi 4A & $\begin{array}{l}\text { Samsung Galaxy } \\
\text { A30 }\end{array}$ \\
\hline Cipset & $\begin{array}{l}\text { Mediatek } \\
\text { MT6762 } \\
\text { Helio P22 } \\
\end{array}$ & $\begin{array}{l}\text { Qualcomm } \\
\text { MSM8917 } \\
\text { Snapdragon } 425\end{array}$ & Exynos 7904 \\
\hline Processor & $\begin{array}{l}\text { Octa-core } \\
2.0 \mathrm{GHz} \\
\text { Cortex- } \\
\text { A53 }\end{array}$ & $\begin{array}{l}\text { Quad-core Max } \\
1.40 \mathrm{GHz}\end{array}$ & $\begin{array}{l}\text { Octa-core }(2 \times 1.8 \\
\text { GHz Cortex-A73 } \\
\& 6 \times 1.6 \mathrm{GHz} \\
\text { Cortex-A53) }\end{array}$ \\
\hline GPU & $\begin{array}{l}\text { PowerVR } \\
\text { GE8320 }\end{array}$ & Adreno 308 & Mali-G71 MP2 \\
\hline Ram & $4 \mathrm{~GB}$ & $2 \mathrm{~GB}$ & $4 \mathrm{~GB}$ \\
\hline Camera & $13 \mathrm{MP}$ & $13 \mathrm{MP}$ & $16 \mathrm{MP}, 5 \mathrm{MP}$ \\
\hline Resolution & $\begin{array}{l}720 \times 1520 \\
\text { pixels, } \\
19: 9 \text { ratio }\end{array}$ & $\begin{array}{l}720 \times 1280 \\
\text { pixels, 16:9 } \\
\text { ratio }\end{array}$ & $\begin{array}{l}1080 \times 2340 \\
\text { pixels, 19.5:9 } \\
\text { ratio }\end{array}$ \\
\hline $\begin{array}{l}\text { Android } \\
\text { Version }\end{array}$ & $\begin{array}{l}\text { Android } \\
8.1 \text { (Oreo) }\end{array}$ & $\begin{array}{l}\text { Android } 7.1 .2 \\
\text { (Nougat) }\end{array}$ & Android 10 \\
\hline
\end{tabular}

Which test results were carried out to see whether the tests on each one went well in accordance with the expected results in the Table 2 . The test results can be seen in the table 3 .

Table 3. Test Results of Each Smartphone

\begin{tabular}{|l|c|c|c|c|}
\hline \multirow{2}{*}{ Testing } & \multicolumn{3}{|c|}{$\begin{array}{c}\text { Testing Result } \\
\text { (Successful) }\end{array}$} & \multirow{2}{*}{ Description } \\
\cline { 2 - 4 } & D1 & D2 & D3 & \\
\hline Instal Apk & Yes & Yes & Yes & \\
\hline $\begin{array}{l}\text { Run the installed } \\
\text { application }\end{array}$ & Yes & Yes & Yes & \\
\hline $\begin{array}{l}\text { Starting AR } \\
\text { Camera and } \\
\text { Favorites }\end{array}$ & Yes & Yes & Yes & $\begin{array}{c}\text { Each device has a } \\
\text { difference when } \\
\text { starting the camera }\end{array}$ \\
\hline $\begin{array}{l}\text { Detection of } \\
\text { markers that are } \\
\text { incompatible with } \\
\text { the system }\end{array}$ & Yes & Yes & Yes & \\
\hline $\begin{array}{l}\text { Detection of the } \\
\text { same and adjusted } \\
\text { markers (Marker } \\
\text { Based Tracking) }\end{array}$ & Yes & Yes & Yes & $\begin{array}{c}\text { Frame rate (fps) will } \\
\text { hrop on devices that }\end{array}$ \\
\hline $\begin{array}{l}\text { Color button is } \\
\text { pressed }\end{array}$ & Yes & Yes & Yes of \\
\hline $\begin{array}{l}\text { The info button is } \\
\text { pressed }\end{array}$ & Yes & Yes & Yes & \\
\hline $\begin{array}{l}\text { The favorite } \\
\text { button is pressed }\end{array}$ & Yes & Yes & Yes & \\
\hline $\begin{array}{l}\text { The video button } \\
\text { is pressed }\end{array}$ & Ya & Ya & Ya & \\
\hline $\begin{array}{l}\text { Video player } \\
\text { playback }\end{array}$ & Yes & Yes & Yes & \\
\hline $\begin{array}{l}\text { Favorite } \\
\text { motorcycle button } \\
\text { is pressed }\end{array}$ & Yes & Yes & Yes & \\
\hline $\begin{array}{l}\text { Rotation, Grab, } \\
\text { Scale on favorite } \\
\text { camera menu }\end{array}$ & Yes & Yes & Yes & \\
\hline
\end{tabular}

The next test is testing the Response Time Loading for AR Cameras and AR Favorites to see how long it takes to load the camera on several devices, the test results can be seen in Table 4 .
Table 4. Camera Load Test

\begin{tabular}{|l|r|r|r|}
\hline \multirow{2}{*}{ Proses } & \multicolumn{4}{|c|}{ Respond Time(s) } \\
\cline { 2 - 5 } & D1 & D2 & D3 \\
\hline $\begin{array}{l}\text { Loading AR } \\
\text { Camera }\end{array}$ & 7.27 & 12.2 & 5.1 \\
\hline $\begin{array}{l}\text { Loading AR } \\
\text { Camera Favorit }\end{array}$ & 4.07 & 5.89 & 3.5 \\
\hline
\end{tabular}

In the table above it is concluded that the higher the android specifications, the faster loading on the camera. The next test is to find out how smooth the application is when a 3D object appears on the camera. Augmented Reality can be seen in the table 5 .

Table 5. Frame Rate

\begin{tabular}{|c|l|c|c|c|}
\hline \multirow{2}{*}{ No } & \multirow{2}{*}{ Objek 3D } & \multicolumn{3}{|c|}{ Frame Rate per Second } \\
\cline { 3 - 5 } & & D1 & D2 & D3 \\
\hline 1 & Objek 3D Vario & 11 & 14 & 24 \\
\hline 2 & Objek 3D Beat & 42 & 18 & 38 \\
\hline 3 & Objek 3D PCX & 30 & 27 & 28 \\
\hline 4 & Objek 3D Genio & 17 & 20 & 25 \\
\hline 5 & Objek 3D Scoppy & 16 & 20 & 28 \\
\hline 6 & Objek 3D Adv & 14 & 22 & 23 \\
\hline
\end{tabular}

In the table above, it can be concluded that the fps test carried out on 3 devices has a difference in fps where in D1 the beat object and pcx object are the highest and D3 the vario, genio, scoppy and Adv objects are the highest. The next test is to find out the distance between the AR camera and the brochure or marker that will bring up $3 \mathrm{D}$ objects which can be seen in table 6 .

Table 6. Distance of Camera

\begin{tabular}{|l|c|c|c|}
\hline \multirow{2}{*}{ Distance } & \multicolumn{3}{|c|}{ Success Yes/no } \\
\cline { 2 - 4 } & D1 & D2 & D3 \\
\hline $5 \mathrm{~cm}$ & No & No & No \\
\hline $15 \mathrm{~cm}$ & No & Yes & Yes \\
\hline $30 \mathrm{~cm}$ & Yes & Yes & Yes \\
\hline $45 \mathrm{~cm}$ & Yes & Yes & Yes \\
\hline $60 \mathrm{~cm}$ & Yes & Yes & Yes \\
\hline
\end{tabular}

In the table above it is concluded that the D1 camera at a distance of $5 \mathrm{~cm}$ and $15 \mathrm{~cm}$ the $3 \mathrm{D}$ object cannot be read, while at a distance of $5 \mathrm{~cm}$ all devices cannot.

\section{CONCLUSION}

The matic motorbike augmented reality application is made using the Unity game engine with the Vuforia SDK which helps in making tracking in augmented reality which of course the application created can help customers to be able to see the visualization of motorbike products directly from a smartphone.

The suggestions are taken from some of the results from disagreeing with the results of the Honda Matic Augmented Reality application respondents for further information, namely that the 3D motor object model can be more detailed than the previous one, the information in the application can be clearer, the music from the application is better, and favorite features in the 
application can use the markerless method which makes it easier for users to place the 3D motor object as desired. Finally, the application suggestion for further development is that if the smartphone camera is pointed at the motor marker, the $3 \mathrm{D}$ object will change according to the color of the motorbike in the brochure and the application can be available on other platforms such as IOS.

\section{REFERENCES}

Ardhianto E., W. Hadikurniawati, dan E. Winarno. 2012. "Augmented Reality Objek 3 Dimensi dengan Perangkat Artoolkit dan Blender." Jurnal Teknologi Informasi DINAMIK 107-117.

Hadi F., R. Permana, dan S. Yulanda. 2018. "Penerapan Augmented Reality Pada Brosur YAMAHA Tjahaja Baru Untuk Promosi Berbasis Android ( Studi Kasus Di Yamaha Tjahaja Baru )." Lppm Upi Yptk 1-8.

Hermawan L., dan Mochamad H. 2015. "Pemanfaatan Augmented Reality Sebagai Media Informasi." Seminar Nasional Teknologi Informasi dan Komunikasi 2015 1-8.

Hunaepi A. 2016. "Assembly Augmented Reality Terhadap Desain Iklan Sebuah Mobil Berbasis Android". Proposal Skripsi. Tidak Diterbitkan. Universitas Pamulang: Pamulang.

Lorena S., dan J. Purnamasari. 2019. "Pengembangan Aplikasi Promosi Produk Handphone Menggunakan Teknologi Augmented Reality Pada Mobile Android." Jurusan Teknik Komputer Universitas Komputer Indonesia 1-8.

Reynaldi D. 2018. "Rancang Bangun Aplikasi Mobile Untuk Media Promosi Kaos Berbasis Augmented Reality", Program Studi Teknik Informatika

Riyans S. 2018. "Assembly Augmented Reality Sebagai Media Pemasaran Berbasis Android Pada Brosur Handphone". Artikel Skripsi. Diterbitkan. Universitas Nusantara PGRI Kediri: Kediri.

Roedavan R. 2016. Unity Tutorial Game Engine. Bandung: INFORMATIKA.

Satria B., dan Prihandoko. 2018. "Assembly Metode Marker Based Tracking Pada Aplikasi Bangun." Tesis Magister Komputer Universitas AMIKOM Yogyakarta 1-5.

Selvia L., dan P. Juwita. 2019. "Pengembangan Aplikasi Promosi Produk Handphone Menggunakan Teknologi Augmented Reality Pada Mobile Android." Jurusan Teknik Komputer Universitas Komputer Indonesia 18.

Siltanen S. 2012. Theory and applications of markerbased augmented reality. Vuorimiehentie: VTT.

Setyawan. 2016. "Analisis Penggunaan Metode Marker Tracking Pada Augmented Reality Alat Musik Tradisional Jawa Tengah". Jurnal Teknik Mesin, Elektro dan Ilmu Komputer.

Sprinting. 2017. Berbagai Macam Jenis dan Ukuran $\begin{array}{lllll}\text { Brosur. } & 12 & 22 . & \text { Diakses } & 10\end{array}$ 2019.https://solusiprinting.com/berbagai-macamjenis-dan-ukuran-brosur/.
Wicaksono I., F. Hakim, dan V. Utomo. 2016. "Motor Matic Vario Berbasis Web ( Studi Kasus : Bengkel Jozz Motor Cangkiran )." Jurnal Transformatika 4958. 
